\title{
Bio-Prospecting for Broad Spectrum Antibiotic Producing Actinomycetes Isolated from Virgin Soils in Kericho County, Kenya
}

\author{
Mercy Chepkurui Rotich1, Esther Magiri'1 , Christine Bii ${ }^{2}$, Naomi Maina ${ }^{*}$ \\ ${ }^{1}$ Department of Biochemistry, Jomo Kenyatta University of Agriculture and Technology, Nairobi, Kenya \\ ${ }^{2}$ Centre for Microbiology Research, Kenya Medical Research Institute, Nairobi, Kenya \\ Email: *nmaina@jkuat.ac.ke
}

How to cite this paper: Rotich, M.C., Magiri, E., Bii, C. and Maina, N. (2017) Bio-Prospecting for Broad Spectrum Antibiotic Producing Actinomycetes Isolated from Virgin Soils in Kericho County, Kenya. Advances in Microbiology, 7, 56-70. http://dx.doi.org/10.4236/aim.2017.71005

Received: November 18, 2016

Accepted: January 10, 2017

Published: January 13, 2017

Copyright $\odot 2017$ by authors and Scientific Research Publishing Inc. This work is licensed under the Creative Commons Attribution International License (CC BY 4.0).

http://creativecommons.org/licenses/by/4.0/

\begin{abstract}
Antimicrobial drug resistance is a rising concern in the treatment of infectious diseases and necessitates the need for discovery of novel, potent antimicrobial compounds to combat antibiotic resistance. Since natural environment remains a potential source of novel antimicrobial products, this preliminary study was performed to test the potential of soils from Kericho County for antibiotic-producing Actinomycetes. Soil samples (214) were randomly collected from virgin soils of Kipkelion East, Kipkelion West, Belgut, Ainamoi, Sigowet and Bureti sub-counties in Kericho County from a depth of between $11 \mathrm{~cm}-16 \mathrm{~cm}$ from the surface of the soil profile. A total of 107 Actinomycetes were isolated and screening was done using modified agar disc diffusion method of which only 39 (36.4\%) showed antimicrobial activity against five of the six test isolates that included reference strains Staphylococcus aureus (ATCC 25923), Escherichia coli (ATCC 25922) and Candida albicans (ATCC 90028) and three clinical strains Trichophyton mentagrophyte, Microsporum gypseum and Methicillin Resistant Staphylococcus aureus. Two of the isolates showed activity against MRSA and four isolates showed a higher potency than the standard drug Chloramphenicol $(30 \mu \mathrm{g})$ against $S$. aureus. Most of the isolates (41.0\%) also showed good antimicrobial activity against $T$. mentagrophyte, though they lower than the control drug Itraconazole $(2 \mu \mathrm{g} / \mathrm{ml})$, they were statistically significant. DNA from the isolates was extracted and the 16S rRNA gene was amplified using primers specific for Actinomycetes. The amplified gene was sequenced and phylogeny analysis was done. The $16 \mathrm{~S}$ rRNA gene was able to be amplified in only 15 of these isolates. Sequencing showed that $93.3 \%$ were of the genus Streptomyces while $6.7 \%$ were of the genus Rhodococcus. From the results, the soils from this region harbour Actinomycetes that may have good potential of producing novel antibiotics against gram positive bacteria and dermatophytes.
\end{abstract}

\section{Keywords}

Actinomycetes, Antimicrobial Activity, Kericho County, Disc Diffusion, 16S rRNA 


\section{Introduction}

Natural products remain to be the most promising resource for discovery of novel bioactive metabolites [1]. Many soil-inhabiting bacteria are known to produce secondary metabolites to suppress microorganisms competing for the same resources [2]. Actinomycetes are the most widely distributed microbes inhabiting the soil environment. They comprise about $50 \%$ of the uncultivable soil microbes and therefore, form the most dominant and significant group among the soil microbial community. They are the microorganisms responsible for the characteristic earthy smell [3] [4].

Actinomycetes secrete secondary metabolites which have different valuable capacities including; production of antibiotics, nutritional materials, cosmetics, enzymes, antitumor agents, enzyme inhibitors, immune modulators, vitamins and also play a major role in the recycling of organic matter in soil. They therefore, provide many important bioactive compounds of high commercial value and continue to be routinely screened for new bioactive substances [2] [5] [6]. Approximately two thirds of the naturally occurring antibiotics have been isolated from Actinomycetes [7], most of which are from the genera Streptomyces and Micromonospora [8].

Antimicrobial drug resistance in infectious diseases is the second leading cause of death in the world today [9]. Antibiotics are important in the treatment of infectious diseases. However, with the current increase of bacterial resistance, there is need to search for new antimicrobial compounds to combat the threat of antibiotic-resistant bacteria. The use of the current antibiotics available in the market is facing many challenges due to resistance that has been formed by the pathogenic micro-organisms. This therefore, has become a major public health concern and there is need for new and efficient antibiotics. Many studies have been done where Actinomycetes have been isolated from different places including soil, mountains, swamps and the marine environment [2] [10] [11] [12] [13] [14] [15]. This has yielded good results where antibiotics against different gram positive and gram negative bacteria have been extracted. Also antibiotics with good activity on fungi and some that have shown to have anti-tumour activities have been extracted from metabolites of these Actinomycetes. More research is going on to come up with new antibiotics. Therefore, this study was designed to bio-prospect for novel antibiotic producing Actinomycetes. Kericho County has different types of soil and also has exotic forests which may have novel Actinomycetes and hasn't been explored.

\section{Materials and Methods}

\subsection{Study Site}

The soil samples were collected from Kericho County. It is within the Rift Valley Province of Kenya. It has an area of $2111 \mathrm{~km}^{2}$ and lies between longitude $35^{\circ} 02^{\prime}$ and $35^{\circ} 40^{\prime}$ East and between the equator and latitude $0^{\circ} 23^{\prime}$ South. It's located in a region with high altitude and therefore, its climate is characterized by rains. The soil $\mathrm{pH}$ ranges from strongly acidic (4.78) to slightly alkaline (7.15) [16]. Sampling was done by simple randomization. A radius of 2 kilometers was measured from one sampling point to the other. The sampling sites included: Kipkelion East, Kipkelion West, Ainamoi, Belgut, Sigowet and Bureti (Figure 1). 


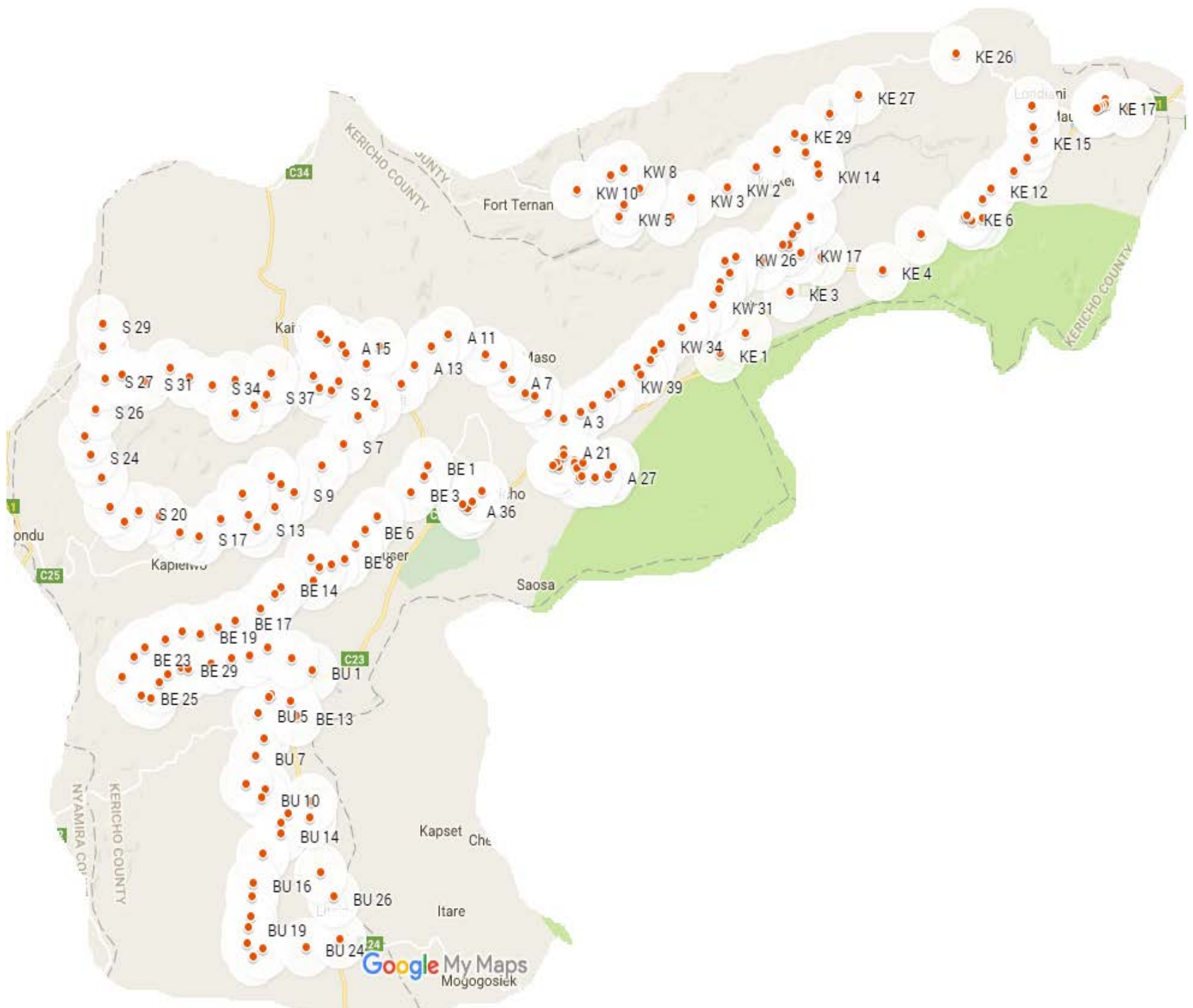

Figure 1. Key: KW-Kipkelion West, KE-Kipkelion East, S-Sigowet, A-Ainamoi, BU-Bureti, BE-Belgut.

\subsection{Soil Sampling}

Two hundred and fourteen soil samples were randomly collected at a depth of approximately $11 \mathrm{~cm}-16 \mathrm{~cm}$ from the surface of the soil profile as this is where Actinomycetes are abundant [3]. The soil was scoped using a sterile spoon and put in labeled sterile zip lock bags. The soils were air dried at room temperature for one week to reduce the population of gram negative bacteria [10]. After air drying, samples were repacked and transported to Kenya Medical Research Institute's Mycology Laboratory at the Centre for Microbiology Research.

\subsection{Isolation and Cultivation of Actinomycetes}

Actinomycetes were isolated by serial dilution method as described previously by Gebreyohannes et al. 2013 [17]. The plates were incubated aerobically at $30^{\circ} \mathrm{C}$ for $7-10$ days and observed periodically for growth of Actinomycetes. Suspected colonies were 
identified by their chalky, firm and leathery texture [14]. The colonies were picked and sub cultured for purity by streaking on Starch Casein agar. Pure colonies were then inoculated into $1.5 \mathrm{~mL}$ of $15 \%$ sterile glycerol stocking solution and stored at $-35^{\circ} \mathrm{C}$ for further analysis.

\subsection{Test Organisms}

Six test organisms obtained from the Mycology Laboratory, Centre for Microbiology Research at the Kenya Medical Research Institute (KEMRI) were used. They included: gram positive strain of Staphylococcus aureus (ATCC 25923), gram negative strain of Escherichia coli (ATCC 25922), yeast Candida albicans (ATCC 90028), two clinical isolates of molds Trichophyton mentagrophyte and Microsporum gypseum and a resistant clinical isolate strain of Methicillin Resistant Staphylococcus aureus.

\subsection{Screening for Antimicrobial Activity}

The stocked isolates were revived by culturing on Nutrient Agar plates (Oxoid, USA) and screening done using modified agar disc diffusion method as described by Kirby Bauer 1979 [18]. Sterilized Whatman No. 1 paper discs (6 mm in diameter) were impregnated with $15 \mu \mathrm{l}$ of the 10 days old culture broth and placed on Mueller Hinton Agar inoculated with the test microorganisms. They were then incubated at $37^{\circ} \mathrm{C}$ for 24 hours for bacteria and at $30^{\circ} \mathrm{C}$ for 48 hours for yeast and for 96 hours for the molds. The bioactive isolates were identified by measuring the inhibition zone in millimeters (mm).

Conventional antibiotics were used as positive controls namely: Chloramphenicol $(30 \mu \mathrm{g})$ for bacteria and Itraconazole $(2 \mu \mathrm{g} / \mathrm{ml})$ for fungi while a disc impregnated with normal saline was used as a negative control.

The isolates that showed antimicrobial activity were further screened for activity against Methicillin Resistant Staphylococcus aureus also using Kirby Bauer disc diffusion technique.

\subsection{Morphological and Biochemical Characterization}

The Actinomycetes isolates that showed positive results in antimicrobial screening were characterized morphologically, biochemically and also Gram staining was done. The isolates were sub cultured on Starch Casein Agar plates and incubated at $30^{\circ} \mathrm{C}$ for $7-10$ days. Thereafter, the colour of aerial mycelium, reverse pigments and nature of colonies were observed [19]. Modified cover-slip culture technique as described by [20] was used to observe the characteristics of hyphae and arrangement of spores at high power magnification. Corn meal agar (Oxoid, USA) was used in culturing. Different biochemical tests namely; Casein hydrolysis, Simon citrate, urea hydrolysis and catalase test were carried out to aid in presumptive identification of Actinomycetes. The tests were done as described by [21].

\subsection{Genomic DNA Extraction and PCR Amplification}

Pure sub-cultures of the Actinomycetes with antimicrobial activity were freshly cultured on nutrient agar plates for six days. A loop full colony was picked for use in the 
extraction of the total genomic DNA. The extraction process was based on Qiagen DNA Extraction kit protocol. The extracted DNA was stored at $-20^{\circ} \mathrm{C}$ in cryo-vials.

Total DNA from each isolate was used as a template for amplification of the $16 \mathrm{~S}$ rDNA gene. The 16S rRNA gene is a conserved gene in the bacteria [22]. The full length of the 16S rDNA sequence was amplified using the following group specific pair of primers; F-Act 243 (5'-GGATGAGCCCGCGGCCTA-3') and R-Act A3

(5'-CCAGCCCCACCTTCGAC-3') described by [23]. A final reaction volume of $50 \mu \mathrm{l}$ was prepared containing; $1 \mu \mathrm{l}$ of genomic DNA, $5 \mu \mathrm{l}$ of 10x Genescript Taq Buffer, $3 \mu \mathrm{l}$ of $2.5 \mathrm{mM}$ dNTPs, $0.4 \mu \mathrm{l}$ of $20 \mathrm{mg} / \mathrm{ml}$ BSA, $0.5 \mu \mathrm{l}$ of $5 \mathrm{U}$ Genescript Taq polymerase and $1 \mu \mathrm{l}$ of 20 pmole each primer. Amplifications were then carried out according to the following profile: $10 \mathrm{~min}$ at $95^{\circ} \mathrm{C}$ and 35 cycles of $94^{\circ} \mathrm{C}$ for $1 \mathrm{~min}, 60^{\circ} \mathrm{C}$ for $1 \mathrm{~min}$ and $72^{\circ} \mathrm{C}$ for $1 \mathrm{~min}, 45 \mathrm{~s}$, followed by $10 \mathrm{~min}$ at $72^{\circ} \mathrm{C}$. Amplification products were analyzed by electro-phoresis in $2 \%(\mathrm{w} / \mathrm{v})$ agarose gels stained with ethidium bromide.

\subsection{Sequencing of $16 \mathrm{~S}$ rDNA Gene and Phylogenetic Analysis}

The PCR products were then purified using the QIAquick ${ }^{\circledR}$ PCR purification Kit from Qiagen and were sent to Macrogen Netherlands for sequencing. The primers used in amplification were the ones used in sequencing of both forward and reverse strands.

A contig, which is a consensus sequence of both the reverse and forward sequence, was generated using the BioEdit software aligner [24]. The 16S rDNA sequences generated were compared to sequences in the National Centre for Biotechnology Information (NCBI) GenBank database using the Basic Alignment Search Tool (BLAST) [25]. Phylogenetic and molecular evolutionary analysis was then conducted using MEGA version 6 [26]. The sequences were aligned using the MUSCLE program against the nearest neighbours and the evolutionary history was inferred using the NeighborJoining method [27]. The evolutionary distances were computed using Maximum Composite Likelihood model [28]. The bootstrap consensus tree inferred from 1000 replicates [29] was taken to represent the evolutionary history of the taxa analyzed.

\subsection{Statistical Analysis}

The antimicrobial results obtained were analyzed using one way ANOVA to compare the level of significance between the isolates' antimicrobial activities and the positive control using SPSS version 20.

\section{Results}

\subsection{Isolated Actinomycetes}

A total of 107 Actinomycetes were isolated from the soil samples. The morphological appearance of both obverse $(1 \& 2)$ and reverse $(3 \& 4)$ of the different isolates is shown in Figure 2.

After incubation for 10 days, the colonies had different colours like yellow, red, white and grey as shown by the representative isolates in Figure 2. The textures of $90 \%$ of the isolates were hard to scrap being some characteristics of Actinomycetes while $10 \%$ were easier to pick. Figure 3 shows representative isolates of Actinomycetes that had highly intertwined hyphae (A) and clustered and chain of spores (B). All the isolates 


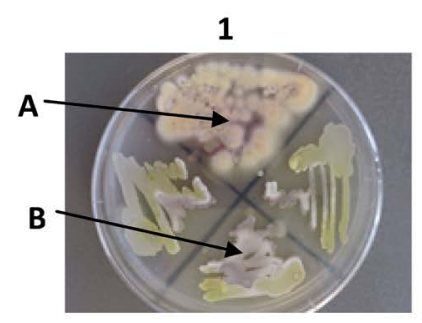

3

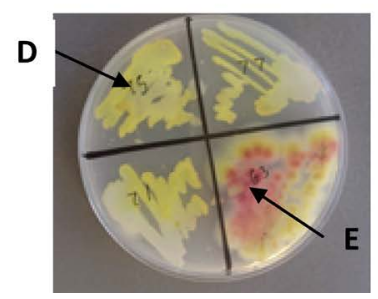

2

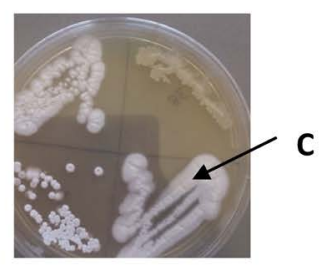

4

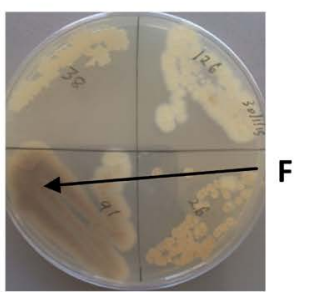

A: Light Yellowish red leathery colony

B: Greyish, whitish chalky colony

C: White wrinkled colony

D: Bright yellow substrate mycelium

E: Red substrate mycelium

F: Brownish substrate mycelium

Figure 2. 1 and 2 show aerial mycelium while 3 and 4 show the substrate (vegetative) mycelium on starch casein agar plates.
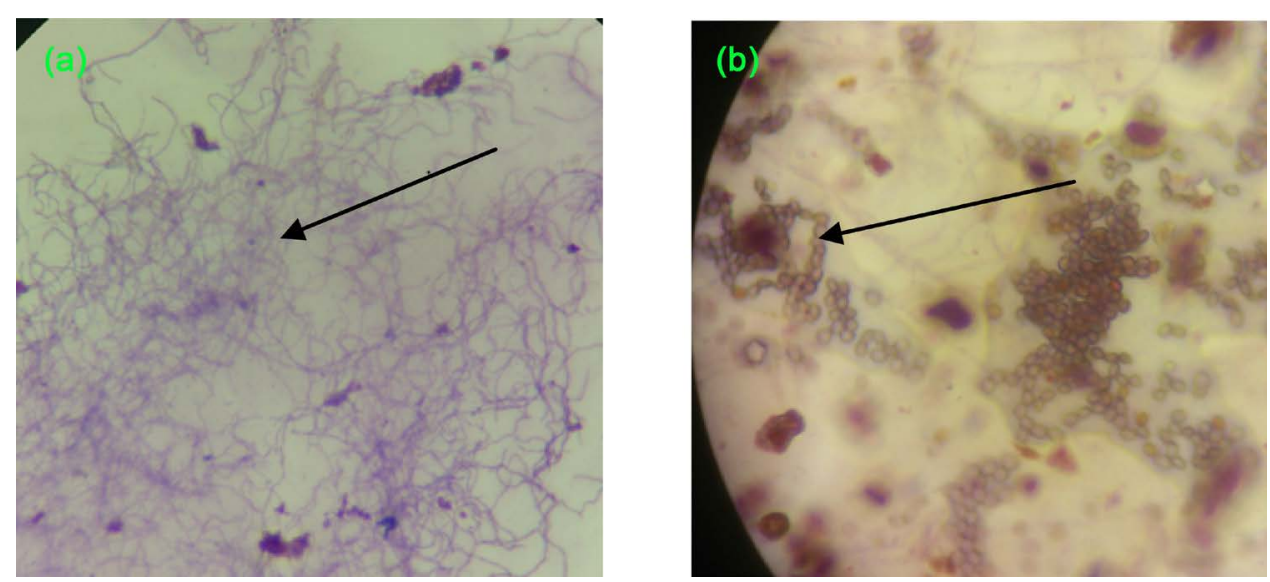

Figure 3. (a) shows intertwined hyphae while (b) shows chain of spores of representative Actinomycetes isolates at Mag x1000.

were gram positive as they retained the primary colour which is a characteristic of Actinomycetes.

\subsection{Antimicrobial Activity Screening of the Isolated Actinomycetes}

Out of the 107 isolated Actinomycetes, only 39 (36.4\%) showed antimicrobial activity against the five of the six test isolates with inhibition zones from $6 \mathrm{~mm}$ to $34 \mathrm{~mm}$. Figure 4 shows the number of isolates that were active against the different test pathogens.

The antimicrobial activity of all the isolates tested against $S$. aureus (SA) was statistically significant $(\mathrm{P}<0.001)$ (Table 1$)$. The inhibition zones of IS30, IS42, IS71 and IS77 were at the maximum of $30.00 \mathrm{~mm}, 30.33 \mathrm{~mm}, 27.00 \mathrm{~mm}$ and $32.67 \mathrm{~mm}$ respectively against SA and were significantly higher than the standard drug Chloramphenicol (23 $\mathrm{mm}$ ). The zones of inhibition for Isolates IS6 and IS40 tested against $C$. albicans (CA) were statistically significant $(\mathrm{P}<0.001)$; however, they were lower than that of the standard drug Itraconazole $(29 \mathrm{~mm})$. None of the Isolates was active against E. coli (EC). 


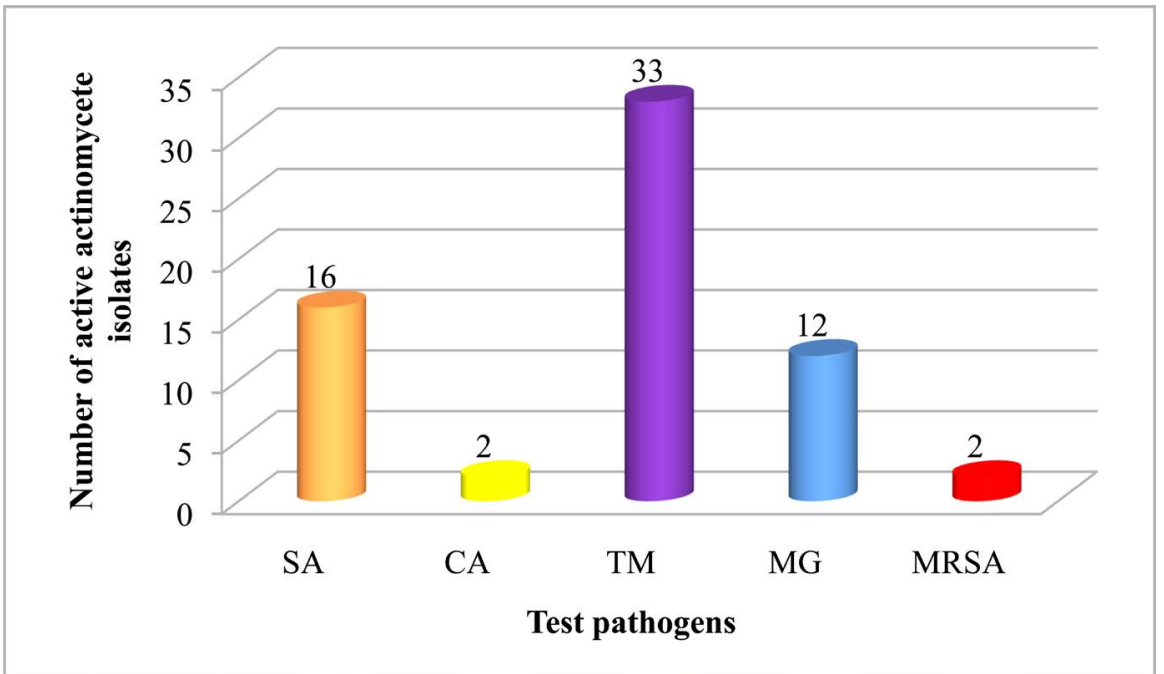

Note: SA: Staphylococcus aureus, CA: Candida albicans, TM: Trichophyton mentagrophyte, MG: Microsporum gypseum, MRSA: Methicillin Resistant Staphylococcus aureus.

Figure 4. Proportion of the isolated Actinomycetes with antibiotic activity against the test pathogens.

Table 1. Inhibition zones ( $\mathrm{mm}$ ) exhibited by metabolites from some of the Isolated Actinomycetes.

\begin{tabular}{|c|c|c|c|c|c|c|}
\hline \multirow{2}{*}{ ISOLATES } & \multicolumn{6}{|c|}{ Test Pathogens } \\
\hline & SA & EC & $\mathrm{CA}$ & TM & MG & MRSA \\
\hline IS6 & - & - & $10.33 \pm 0.58$ & - & $11.67 \pm 1.16$ & - \\
\hline IS7 & - & - & - & $22.67 \pm 0.58$ & - & - \\
\hline IS30 & $30.00 \pm 1.00^{\mathrm{a}}$ & - & - & $26.33 \pm 0.58$ & $18.33 \pm 0.58$ & _- \\
\hline IS34 & - & - & - & $20.33 \pm 0.58$ & - & - \\
\hline IS38 & - & - & - & $30.33 \pm 0.58$ & - & - \\
\hline IS40 & - & - & $8.33 \pm 0.58$ & - & - & - \\
\hline IS42 & $30.33 \pm 0.58^{\mathrm{a}}$ & - & - & $23.67 \pm 0.58$ & - & - \\
\hline IS53 & - & - & - & $21.33 \pm 1.16$ & - & - \\
\hline IS55 & $6.33 \pm 0.58$ & - & - & $19.67 \pm 0.58$ & - & - \\
\hline IS58 & - & - & - & $32.67 \pm 0.58$ & $17.67 \pm 0.58$ & $20.33 \pm 0.33$ \\
\hline IS63 & - & - & - & $24.67 \pm 0.58$ & $11.67 \pm 0.58$ & - \\
\hline IS71 & $27.00 \pm 1.00^{\mathrm{a}}$ & - & - & $27.33 \pm 0.58$ & $14.67 \pm 0.58$ & - \\
\hline IS72 & - & - & - & $13.67 \pm 0.58$ & $20.33 \pm 0.58$ & $10.33 \pm 0.33$ \\
\hline IS75 & - & - & - & $34.67 \pm 0.58$ & $18.00 \pm 1.00$ & - \\
\hline IS77 & $32.67 \pm 0.58^{\mathrm{a}}$ & - & - & $25.67 \pm 0.58$ & - & - \\
\hline Control Drug & $23.67 \pm 0.58$ & $25 \pm 0.58$ & $29.67 \pm 0.58$ & $39.67 \pm 0.58$ & $38.33 \pm 0.58$ & $25.33 \pm 0.33$ \\
\hline
\end{tabular}

Note: SA: Staphylococcus aureus, EC: Escherichia coli, CA: Candida albicans, TM: Trichophyton mentagrophyte, MG: Microsporum gypseum, MRSA: Methicillin Resistant Staphylococcus aureus. Superscripted figures indicate higher significant value $(\mathrm{P}<0.001)$ from the control; Inhibition zone diameters mean $\pm \mathrm{SD}$ of the three replications; (-): no antimicrobial activity. 
Most isolates tested (84.6\%) were active against T. mentagrophyte (TM) and most of these isolates were from red soils. The inhibition zones were significantly lower $(\mathrm{P}<$ $0.001)$ from those of Itraconazole $(39 \mathrm{~mm})$ which was the control drug. The inhibition zones of the active isolates tested against $M$. gypseum (MG) were significantly lower $(\mathrm{P}<$ $0.001)$ than that of the control $(38 \mathrm{~mm})$. The two isolates that showed antibiotic activity against the Methicillin resistant $S$. aureus were also statistically significant $(\mathrm{P}<0.01)$. Isolate IS58 showed good activity $(20 \mathrm{~mm})$ compared to Chloramphenicol $(25 \mathrm{~mm})$.

From Table 2, all isolates showed the ability to utilize citrate as the sole carbon source and also they were all catalase positive hence the ability to breakdown hydrogen peroxide to oxygen and water. Isolate IS42, IS53, IS58 and IS72 had the ability to hydrolyze casein. Most of the morphological characteristics observed were characteristics exhibited by Streptomyces species.

\subsection{Amplification and Sequencing}

The DNA from the 39 isolates that showed antimicrobial activity was extracted and the 16S rRNA gene amplified. Only 15 (38.5\%) isolates were able to be amplified as shown in Figure 5. The expected size of about $1200 \mathrm{bp}$ was obtained. The two isolates IS58 and

Table 2. Representative isolates of Actinomycetes showing macroscopic, microscopic and biochemical characteristics.

\begin{tabular}{|c|c|c|c|c|c|c|c|c|}
\hline Isolates & $\begin{array}{c}\text { Aerial } \\
\text { mycelium }\end{array}$ & $\begin{array}{l}\text { Substrate } \\
\text { mycelium }\end{array}$ & Pigmentation & Cell form & $\begin{array}{c}\text { Casein } \\
\text { hydrolysis }\end{array}$ & $\begin{array}{c}\text { Citrate } \\
\text { utilization }\end{array}$ & Urease & Catalase \\
\hline IS30 & Creamish & Cream & None & Short rods & - & + & + & + \\
\hline IS42 & Cream & Cream & None & Long branching hyphae & + & + & + & + \\
\hline IS58 & Mucoid greenish & Light greenish & None & Short rods & + & + & + & + \\
\hline IS63 & Light yellowish red leathery & Red & None & Spores seen & - & + & + & + \\
\hline IS71 & Greyish-whitish chalky & Bright yellow & None & Grouped and single spores & - & + & + & + \\
\hline IS72 & White leathery & White & None & Branched hyphae with spores in twos & + & + & + & + \\
\hline IS75 & Greyish-whitish chalky & Bright yellow & None & Single and double spores & - & + & + & + \\
\hline IS77 & Greyish-whitish chalky & Bright yellow & None & Short rods & - & + & + & + \\
\hline
\end{tabular}

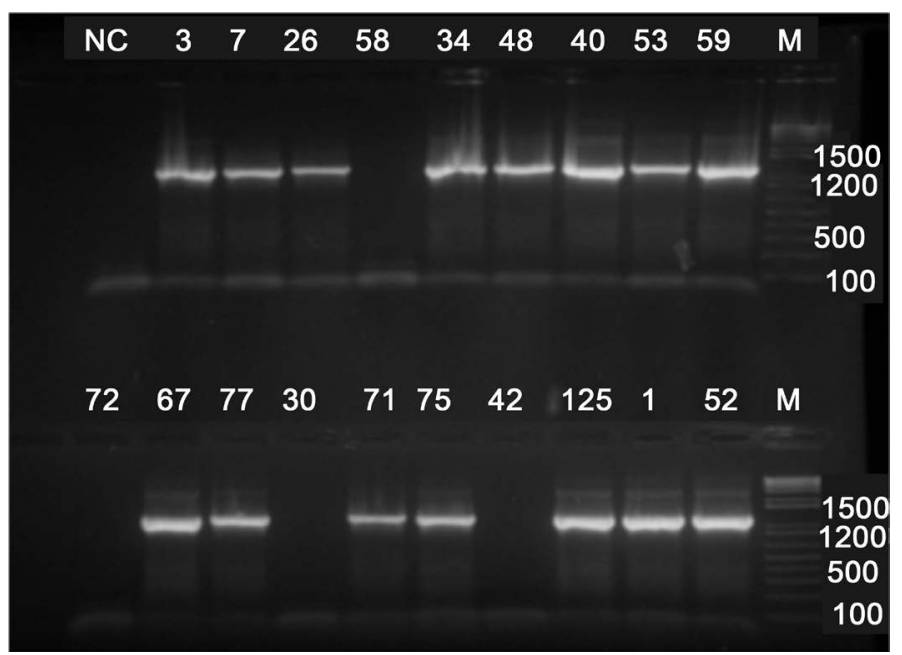

Figure 5. Amplifications of $16 \mathrm{~S}$ rDNA from isolates from the virgin soils from Kericho County. $\mathrm{NC}$ is the negative control while $\mathrm{M}$ is the molecular ladder. 
IS72 that were active against MRSA were among those that were not amplified using this pair of primers.

The 16S rDNA sequences of the 15 isolates were compared with those in NCBI. The BLAST analyses showed that the isolates were members of the Actinomycetes group and most 14 (93.3\%) were closely affiliated to the genus Streptomyces while only one (6.7\%) showed affiliation with members of the genus Rhodococcus. The similarity values were between $98 \%$ and $100 \%$. The phylogenetic tree of representative samples isolated is drawn in Figure 6. It shows the phylogenetic positions of representative isolates.

\section{Discussion}

Natural products are the most promising sources for developing future antibiotics [30] [31]. About 70\% of antibiotics in use have been isolated from Actinomycetes [13] and are known to be the main source of lead compounds for antimicrobial drugs. Kericho county is located in a region with high altitude and the soil $\mathrm{pH}$ ranging from 4.78 to 7.15 [16], hence the possibility of finding novel strains of Actinomycetes.

Out of the total 107 Actinomycete isolates, 39 (36.4\%) showed antimicrobial activity against the test pathogens. About $41.0 \%$ showed antimicrobial activity against $S$. aureus with 4 of these having a higher potency than the standard drug Chloramphenicol (30 $\mu \mathrm{g})$. These isolates therefore showed potent ability of producing effective antibiotics since at that state they were still at their crude state. $S$. aureus is known to be the leading cause of nosocomial infections [32]. Previous study showed that $S$. aureus was the prevalent cause of blood stream infections, skin and soft tissue infection and pneumonia [33]. In this study, $5.1 \%$ showed antimicrobial activity against Methicillin resistant $S$. aureus. One isolate (IS58) showed promising results against MRSA. It showed an inhibition zone of $20 \mathrm{~mm}$ at its crude state as opposed to the standard drug Chloramphenicol $(30 \mu \mathrm{g})$. Similar results have been reported in a study done at Mt. Everest [13]. The metabolites from this isolate could be purified further to get its potency at its minimum inhibitory concentration and also find its components to compare with the standard drugs. However, from this study, these isolates that had antibacterial activity against MRSA showed no activity against $S$. aureus. It was not clear why this was the case and therefore if these metabolites could be purified and its components noted, an explanation could be gotten. Therefore, further studies should be done by extracting and purifying the active compounds.

T. mentagrophyte and M. gypseum on the other hand are dermatophytes which cause infections on keratinized tissues while $C$. albicans mostly cause opportunistic infections. In this study, most of the isolates (84.6\%) had activity against T. mentagrophyte, $30.8 \%$ on $M$. gypseum and $5.1 \%$ on C. albicans. Though none of the isolates were more potent than the standard drug Itraconazole $(2 \mu \mathrm{g} / \mathrm{ml})$, some isolates showed promising results. Isolates IS38, IS58 and IS75 showed good antimicrobial activity of $30.33 \mathrm{~mm}, 32.67 \mathrm{~mm}$ and $34.67 \mathrm{~mm}$ respectively against T. mentagrophyte. Therefore, these isolates with potent activity could be further purified to find out their relative potency. The Actinomycetes from these soils could also be good for production of antifungals especially those active against dermatophytes. Most of these isolates active on $T$. 
mentagrophyte were isolated from the red soils which are known to be acidic. Acidic soils have been reported to harbor Actinomycetes with antifungal activity [11].

The search for antifungals active against dermatophytes has faced difficulties in the past [34]. In previous studies, few isolated Actinomycetes have shown activity against

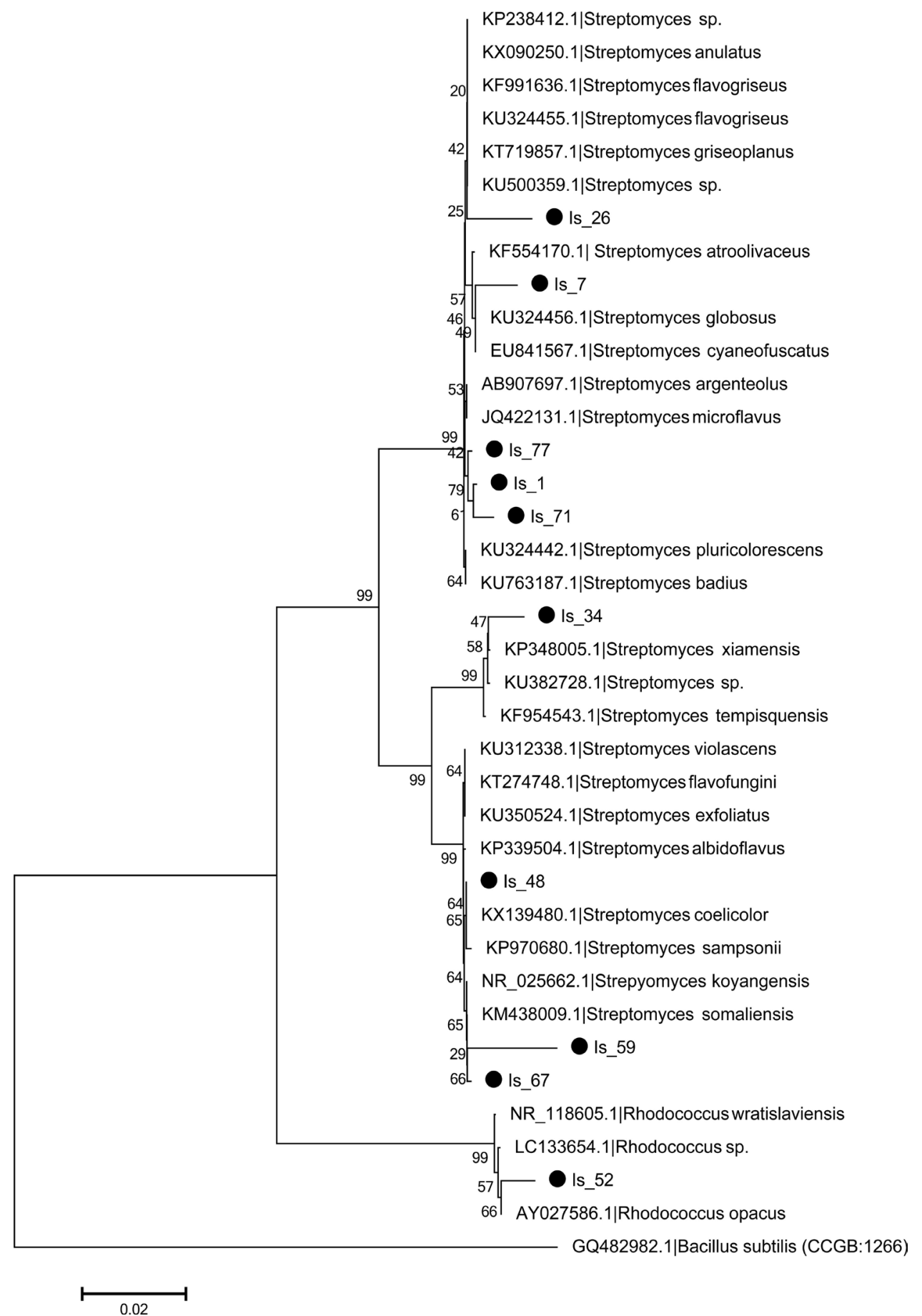

Figure 6. Neighbor joining tree showing the phylogenetic positions of isolates from virgin soil of Kericho County rooted using $16 \mathrm{~S}$ rDNA of Bacillus subtilis as outgroup. The GenBank accession numbers of the strains are indicated. The scale bar indicates $2 \%$ estimated sequence divergence. The percentage of replicate trees in which the associated taxa clustered together in the bootstrap test (1000 replicates) is shown next to the branches. 
these dermatophytes [35] [36] [37]. A study done in Brazil where six Candida sp. and 5 dermatophytes were tested including T. mentagrophyte and M. gypseum showed antibiotic activity only on the Candida sp. [34]. This is in contrast with the current study where there was good activity against the two dermatophytes tested especially against $T$. mentagrophyte. However, a study done in Kenya from soil collected from different national parks has similar results with this study where the Actinomycetes isolated had antibiotic activity against crop fungal pathogen [38]. Since most of the Actinomycetes active on the dermatophytes were isolated on red soil which are known to habour fungi and are acidic, the activity shown as opposed to previous studies could be attributed to the fact that the isolated Actinomycetes have developed protective mechanisms for survival hence produce metabolites active on fungi [39].

In the current study, $90 \%$ of the Actinomycetes isolated had morphological characteristics of Streptomyces sp as earlier documented [19] [40]. The characteristics of Streptomyces noted were white to grayish on the aerial mycelium with brownish substrate mycelium or white-grayish aerial mycelium with yellow substrate mycelium. The biochemical tests showed that $20 \%$ of the isolates tested had the ability to hydrolyze casein, however, most of the isolates were seen to have the ability to produce urease and catalase enzymes and this could be attributed to similar metabolic pathways [41]. All the isolates showed the ability to use citrate as the main carbon source and were catalase positive. This is similar to the results shown for Streptomyces $s p$. isolated in India [42]. The ability of Actinomycetes to produce a variety of extracellular hydrolytic enzymes is of great importance and normally the natural source from which it is isolated influences the kind of enzymes produced by the Actinomycete strain [43] [44]. The dominance of Streptomyces in soil has been documented earlier [4] [45] [46]. Streptomyces $s p$. is also reported to be the most important bacteria in soil as it carries out different ecological functions such as degradation of organic matter and helping in the formation of compost [39] [47]. Therefore, it represents almost up to $90 \%$ of the Actinomycetes' soil diversity [48].

The isolates' consensus sequences of both the reverse and forward sequences of the 16S rDNA gene amplified had a size of between 1204 and 1492 bp though the PCR amplifications showed a single band. Most of the Actinomycete sequences of $16 \mathrm{~S}$ rRNA gene reported are close to these ranges. Only $15(38.5 \%)$ isolates were able to be amplified by these group specific pair of primers. This could be attributed to the fact that the isolates that were not amplified could belong to the rare genera of Actinomycetes and in future more pair of primers should be used including genera specific primers. The isolates that were not able to be amplified included the two (IS58 and IS72) which were active against MRSA and two (IS30 and IS42) that showed higher potency than the control drug against $S$. aureus. Phylogenetic analysis showed that most isolates $93.3 \%$ were aligned to other known Streptomyces sp. and had similarity values of between $98 \%-100 \%$. Previous study on soil samples from a reserved area in Kenya has reported these similar results [38]. Only one isolate aligned with Rhodococcus opacus with a bootstrap value of 67 and a similarity of $99 \%$ and is the first recorded species of $R$ hodococcus sp. on Kenyan soil though Rhodococcus $s p$. was also isolated from Lake Magadi [49]. This Rhodococcus $s$. had antimicrobial activity only on T. mentagrophyte as 
opposed to the one isolated in Lake Magadi that showed activity on E. coli and $P$. aeruginosa. This therefore, suggests that they were of different strains.

\section{Conclusions}

The findings of this study show that soil from this region harbour Actinomycetes which may have good potential of producing novel antibiotics. Also the isolates that showed good zones $>20 \mathrm{~mm}$ could be potential sources of potent broad spectrum antimicrobial agents. Though most of the isolates showed activity that was lower than the control drugs used, they were statistically significant.

Long term use of antifungals has led to increase in resistant strains and in number of opportunistic infections posing a challenge. Therefore, further studies should be carried out on these soils for prospective antifungals that are effective and safe.

\section{Limitations of the Study}

Due to limited funding, extraction and purification of the metabolites were not able to be done. This would have provided more information especially on determining the MIC of the metabolites and also comparing the actual components of the metabolites with the control to see whether there were any novel compounds.

\section{Acknowledgements}

We would like to thank Innovation Centre for Molecular Biology \& Biochemistry (iC$\mathrm{MoB}$ ) under AFRICA ai-JAPAN project for funding this project and the Kenya Medical Research Institute's Mycology lab for allowing us to do the work there. The first author would also want to thank Dr. Anthony Kebira for guiding her through the initial stages of formulation of this work, the lab staff for their assistance and her colleagues for offering a helping hand when she needed it.

\section{Conflict of Interest}

The authors do not have any conflict of interest.

\section{References}

[1] Devi, S.C., Naine, J.S., Nasimunislam, N., Vaishnavi, B. and Mohanasrinivasan, V. (2012) Isolation of Soil Actinomycetes Inhabiting Amrithi Forest for the Potential Source of Bioactive Compounds. Asian Journal of Pharmaceutical and Clinical Research, 5, 4-7.

[2] Velayudham, S. and Murugan, K. (2012) Diversity and Antibacterial Screening of Actinomycetes from Javadi Hill Forest Soil, Tamilnadu, India. Journal of Microbiology Research, 2, 41-46. https://doi.org/10.5923/j.microbiology.20120202.07

[3] Chaudhary, H.S., Soni, B., Shrivastava, A.R. and Shrivastava, S. (2013) Diversity and Versatility of Actinomycetes and Its Role in Antibiotic Production. Journal of Applied Pharmaceutical Science, 3, S83-S94.

[4] Basilio, A., Gonzalez, I., Vicente, M.F., Gorrochategui, J., Cabello, A., Gonzalez, A. and Genilloud, O. (2003) Patterns of Antimicrobial Activities from Soil Actinomycetes Isolated under Different Conditions of $\mathrm{pH}$ and Salinity. Journal of Applied Microbiology, 95, 814823. https://doi.org/10.1046/j.1365-2672.2003.02049.x

[5] Deepa, S., Kanimozhi, K. and Panneerselvam, A. (2014) 16S rDNA Phylogenetic Analysis of 
Actinomycetes Isolated from Marine Environment Associated with Antimicrobial Activities. Journal for Drugs and Medicines, 5, 43-50.

[6] Gopinath, B.V., Vootla, P.K., Jyothi, R. and Reddy, S.K. (2013) Antimicrobial Activity of Actinomycetes Isolated from Coal Mine Soils of Godavari Belt Region, A.P, India. Asian Journal of Experimental Biological Sciences, 4, 518-523.

[7] Okami, Y. and Hotta, K. (1988) 2-Search and Discovery of New Antibiotics. In: Goodfellow, M., Williams, S.T. and Mordarski, M., Eds., Actinomycetes in Biotechnology, Academic Press, London, 33-67. https://doi.org/10.1016/b978-0-12-289673-6.50007-5

[8] Pandey, A., Imran, A., Kailash, S.B., Tanushri, C. and Vidyottma, S. (2011) Isolation and Characterization of Actinomycetes from Soil and Evaluation of Antibacterial Activities of Actinomycetes against Pathogens. International Journal of Applied Biology and Pharmaceutical Technology, 2, 384-392.

[9] Carlet, J. (2012) The Gut Is the Epicentre of Antibiotic Resistance. Antimicrobial Resistance and Infection Control, 1, 39. https://doi.org/10.1186/2047-2994-1-39

[10] Jeffrey, L.S.H. (2008) Isolation, Characterization and Identification of Actinomycetes from Agriculture Soils at Semongok, Sarawak. African Journal of Biotechnology, 7, 3697-3702.

[11] Guo, X., Liu, N., Li, X., Ding, Y., Shang, F., Gao, Y., Ruan, J. and Huang, Y. (2015) Red Soils Harbor Diverse Culturable Actinomycetes That Are Promising Sources of Novel Secondary Metabolites. Applied and Environmental Microbiology, 81, 3086-3103. https://doi.org/10.1128/AEM.03859-14

[12] Kumar, V., Gajraj, S.B. and Omprakash, G. (2013) Terrestrial Actinomycetes from Diverse Locations of Uttarakhnad, India: Isolation and Screening for Their Antibacterial Activity. Iranian Journal of Microbiology, 5, 299-308.

[13] Gurung, T.D., Sherpa, C., Agrawal, V.P. and Lekhak, B. (2009) Isolation and Characterization of Antibacterial Actinomycetes from Soil Samples of Kalapatthar, Mount Everest Region. Nepal Journal of Science and Technology, 10, 173-182.

[14] Rao, K.V.R., Rao, T.R., Kumar, K.S. and Rao, D.B. (2012) Isolation and Screening of Antagonistic Actinomycetes from Mangrove Soil. Journal of Biochemical Technology, 3, 361365.

[15] Olano, C., Carmen, M. and José, A.S. (2009) Antitumor Compounds from Marine Actinomycetes. Marine Drugs, 7, 210-248. https://doi.org/10.3390/md7020210

[16] Andae, G. (2014) Best Fertilisers for Use in Different Counties to Improve Crop Yields. Daily Nation Newspaper, February 2014, 10.

[17] Gebreyohannes, G., Moges, F., Sahile, S. and Raja, N. (2013) Isolation and Characterization of Potential Antibiotic Producing Actinomycetes from Water and Sediments of Lake Tana, Ethiopia. Asian Pacific Journal of Tropical Biomedicine, 3, 426-435. https://doi.org/10.1016/S2221-1691(13)60092-1

[18] Kirby-Bauer (1979) Susceptibility Test with Single, High-Concentration Antimicrobial Disks. Antimicrobial Agents Chemotherapy, 3, 418-424.

[19] Salam, D.M. and Rana, S. (2014) Antimicrobial Potential of Actinomycetes Isolated from Soil Samples of Punjab, India. Journal of Microbiology \& Experimentation, 1, 1-6.

[20] Kandasamy, S., Muthusamy, G., Thangaswamy, S. and Senthilkumar, B. (2012) Screening and Identification of Antibiotic Producing Actinomycetes and Their Antagonistic Activity Against Common Pathogens. World Research Journal of Antimicrobial Agents, 1, 7-10.

[21] Cappuccino, J.G. and Sherman, N. (2002) Microbiology: A Laboratory Manual. 6th Edition, Pearson Education Inc., San Francisco, 15-224.

[22] Kumar, V., Bharti, A., Gusain, O. and Bisht, G.S. (2010) An Improved Method for Isolation of Genomic DNA from Filamentous Actinomycetes. Journal of Engineering and Technology Management, 2, 10-13. 
[23] Monciardini, P., Sosio, M., Cavaletti, L., Chiocchini, C. and Donadio, S. (2002) New PCR Primers for the Selective Amplification of 16S rDNA from Different Groups of Actinomycetes. FEMS Microbiology Ecology, 42, 419-429. https://doi.org/10.1111/j.1574-6941.2002.tb01031.x

[24] Hall, T.A. (1999) BioEdit: A User-Friendly Biological Sequence Alignment Editor and Analysis Program for Windows 95/98/NT. Nucleic Acids Symposium Series, 41, 95-98.

[25] Altschul, S.F., Gish, W., Miller, W., Myers, E.W. and Lipman, D.J. (1990) Basic Local Alignment Search Tool. Journal of Molecular Biology, 215, 403-410. https://doi.org/10.1016/S0022-2836(05)80360-2

[26] Tamura, K., Stecher, G., Peterson, D., Filipski, A. and Kumar, S. (2013) MEGA6: Molecular Evolutionary Genetics Analysis Version 6.0. Molecular Biology and Evolution, 30, 27252729. https://doi.org/10.1093/molbev/mst197

[27] Saitou, N. and Nei, M. (1987) The Neighbor-Joining Method: A New Method for Reconstructing Phylogenetic Trees. Molecular Biology and Evolution, 4, 406-425.

[28] Tamura, K., Nei, M. and Kumar, S. (2004) Prospects for Inferring Very Large Phylogenies by Using the Neighbor-Joining Method. Proceedings of the National Academy of Sciences of the United States of America, 101, 11030-11035.

https://doi.org/10.1073/pnas.0404206101

[29] Felsenstein, J. (1985) Confidence Limits on Phylogenies: An Approach Using the Bootstrap. Evolution, 39, 783-791. https://doi.org/10.2307/2408678

[30] Cragg, G.M. and Newman, D.J. (2013) Natural Products: A Continuing Source of Novel Drug Leads. Biochimica et Biophysica Acta, 1830, 3670-3695. https://doi.org/10.1016/j.bbagen.2013.02.008

[31] Sharma, D., Kaur, T., Chadha, B.S. and Manhas, R.K. (2011) Antimicrobial Activity of Actinomycetes against Multidrug Resistant Staphylococcus aureus, E. coli and Various Other Pathogens. Tropical Journal of Pharmaceutical Research, 10, 801-808. https://doi.org/10.4314/tjpr.v10i6.14

[32] Lowy, F.D. (2003) Antimicrobial Resistance: The Example of Staphylococcus aureus. The Journal of Clinical Investigation, 111, 1265-1273. https://doi.org/10.1172/JCI18535

[33] Diekema, D.J., Pfaller, M.A., Schmitz, F.J., Smayevsky, J., Bell, J., Jones, R.N., Beach, M. and SENTRY Participants Group (2001) Survey of Infections Due to Staphylococcus Species: Frequency of Occurrence and Antimicrobial Susceptibility of Isolates Collected in the United States, Canada, Latin America, Europe, and the Western Pacific Region for the SENTRY Antimicrobial Surveillance Program, 1997-1999. Clinical Infectious Diseases, 32, S114S132. https://doi.org/10.1086/320184

[34] Spadari, C., Antunes, T., Teixeira, R., Minotto, E., Fuentefria, A.M. and Sand, S. (2013) Antifungal Activity of Actinobacteria against Fungus Isolates of Clinical Importance. Revista Brasileira de Biociências (Brazillian Journal of Biosciences), 11, 439-443. http://www.ufrgs.br/seerbio/ojs/index.php/rbb/article/view/2762

[35] Augustine, S.K., Bhavsar, S.P. and Kapadnis, B.P. (2005) Production of a Growth Dependent Metabolite Active against Dermatophytes by Streptomyces Rochei AK 39. The Indian Journal of Medical Research, 121, 164-170.

[36] Lakshmipat, D.T. and Kannabiran, K. (2009) A Morphological, Biochemical and Biological Studies of Halophilic Streptomyces sp. Isolated from Saltpan Environment. American Journal of Infectious Diseases, 5, 207-213. https://doi.org/10.3844/ajidsp.2009.207.213

[37] Deepa, L.S., Gowthami, K. and Kumar, K.S. (2011) In Vivo Screening of Antimicrobial Activity of Soil Actinomycetes against Human Pathogens. World Journal of Agricultural Sciences, 7, 624-628.

[38] Nonoh, J.O., Lwande, W., Masiga, D., Herrmann, R., Presnail, J.K., Schepers, E., et al. 
(2010) Isolation and Characterization of Streptomyces Species with Antifungal Activity from Selected National Parks in Kenya. African Journal of Microbiology Research, 4, 856864. http://www.academicjournals.org/journal/AJMR/article-abstract/1AEDE3B13179

[39] Crawford, D.L., Lynch, J.M., Whipps, J.M. and Ousley, M.A. (1993) Isolation and Characteristion of Actinomycete Anatgonists of a Fungal Root Pathogen. Applied and Environmental Microbiology, 59, 3899-3905.

[40] Taddei, A., Rodriguez, M.J., Marquez-Vilchez, E. and Castelli, C. (2006) Isolation and Identification of Streptomyces spp. from Venezuelan Soils: Morphological and Biochemical Studies. I. Microbiological Research, 161, 222-231. https://doi.org/10.1016/j.micres.2005.08.004

[41] Sharma, M. (2014) Original Research Article Actinomycetes: Source, Identification, and Their Applications. International Journal of Current Microbiology and Applied Sciences, 3, 801-832.

[42] Dileep, N., Junaid, S., Rakesh, K.N., Kekuda, P. and Onkaraa, R. (2013) Antibacterial Activity of Three Strepyomyces Species Isolated from Soils of Shikaripura, Kanataka, India. Journal of Biological and Scientific Opinion, 1, 173-177.

https://doi.org/10.7897/2321-6328.01307

[43] Saadoun, I., Rawashdeh, R., Dayeh, T., Ababneh, Q. and Mahasneh, A. (2007) Isolation, Characterization and Screening for Fiber Hydrolytic Enzymes-Producing Streptomycetes of Jordanian Forest Soils. Biotechnology, 6, 120-128. https://doi.org/10.3923/biotech.2007.120.128

[44] Sharmin, S., Hossain, T.M. and Anwar, M.N. (2005) Isolation and Characterization of Protease Producing Bacteria Bacillus amovivorus and Optimization of Some Factors of Culture Conditions for Protease Production. Journal of Biological Sciences, 5, 358-362. https://doi.org/10.3923/jbs.2005.358.362

[45] Priyadharsini, P. and Dhanasekaran, D. (2015) Diversity of Soil Allelopathic Actinobacteria in Tiruchirappalli District, Tamilnadu, India. Journal of the Saudi Society of Agricultural Sciences, 14, 54-60. https://doi.org/10.1016/j.jssas.2013.07.001

[46] Han, N.Y., Yi, T.J. and Chia, Y.T. (2013) Antimicrobial Activity of Actinomycetes Isolated from Paya Maga, Sarawak. Jurnal Teknologi (Sciences and Engineering), 62, 17-19. https://doi.org/10.11113/jt.v62.1872

[47] Adegboye, M.F. and Babalola, O.O. (2012) Taxonomy and Ecology of Antibiotic Producing Actinomycetes. African Journal of Agricultural Research, 7, 2255-2261.

[48] Xu, L., Li, Q. and Jiang, C. (1996) Diversity of Soil Actinomycetes in Yunnan, China. Applied and Environmental Microbiology, 62, 244-248.

[49] Ronoh, R.C., Budambula, N.L.M., Mwirichia, R.K. and Boga, H.I. (2013) Isolation and Characterization of Actinobacteria from Lake Magadi, Kenya. African Journal of Microbiology Research, 7, 4200-4206. 
Submit or recommend next manuscript to SCIRP and we will provide best service for you:

Accepting pre-submission inquiries through Email, Facebook, LinkedIn, Twitter, etc. A wide selection of journals (inclusive of 9 subjects, more than 200 journals) Providing 24-hour high-quality service

User-friendly online submission system

Fair and swift peer-review system

Efficient typesetting and proofreading procedure

Display of the result of downloads and visits, as well as the number of cited articles Maximum dissemination of your research work

Submit your manuscript at: http://papersubmission.scirp.org/

Or contact aim@scirp.org 